Христо B.O. аспірант кафедри світової літератури та культури імені О. Мішукова Херсонський державний університет

\title{
ГЕНЕЗА ЛІТЕРАТУРНОГО ПОСТМЕДЕРНІЗМУ: УКРАЇНСЬКА / ЗАХІДНА МОДЕЛЬ
}

У статті здійснено дослідження генези літературного постмодернізму. Особливу увагу приділено дослідженню його західної та української моделей, подано аналіз поглядів сучасних літературознавців стосовно феномену постмодернізму в сучасній літературі. Також автор розкриває основні характеристики та необарокові ознаки постмодерної літератури.

Ключові слова: бароко, тенеза, літературний постмодернізм, необароко, сучасний літературний прочес.

В статье осуществлено исследование генезиса литературного постмодернизма. Особое внимание уделено исследованию его западной и украинской моделей, представлен анализ взглядов современных литературоведов относительно феномена постмодернизма в современной литературе. Также автор раскрывает основные характеристики и необарокковые признаки постмодернистской литературы.

Ключевые слова: барокко, генезис, литературный постмодернизм, необарокко, современный литературный проиесс.

In the article is researched the genesis of literary postmodernism. Chief attention is paid to researching its western and Ukrainian variants, the analysis views of modern literary critics about the phenomenon of literary postmodernism in contemporary literature. The author discloses the main characteristics and neobaroque features of postmodern literature.

Keywords: baroque, genesis, literary postmodernism, neo-baroque, modern literary process. 
Постмодернізм як об'єкт дослідження останнім часом займає одне 3 провідних місць. I це не $є$ дивним, адже він якнайкраще відображає світовідчуття людини зламу епох. Постмодернізм, перш за все, є духовним станом, особливим світосприйняттям, яким характеризується кризова епоха, i для якого характерним $є$ відчуття відчаю, розгубленості, розчарування.

Серед найвидатніших західних вчених, які сприяли концептуальному утвердженню постмодернізму, варто назвати Р. Барта, Ж. Бодрійара, Дж. Ваттімо, Ф. Гватарі, Ж. Дерріда, Ф. Джеймсона, У. Еко, Ю. Крістєву, Ж.-Ф. Ліотара, Р. Рорті, Д. Фоккема, М. Фуко, Ю. Хабермаса, І. Хассана та ін.

Метою нашого дослідження $€$ визначення та порівняння особливостей генези літературного постмодернізму, його західної та української моделей.

Безперечно український варіант різниться від свого західного аналогу, i це не $є$ дивним, адже розвиваються вони у дещо інших культурно-історичних та соціально-економічних реаліях, хоч i мають спільну світоглядно-естетичну платформу. У такому контексті слушною $є$ думка Н. Бедзір про те, що «літературний постмодернізм вивчається, оцінюється, узагальнюється переважно за західноєвропейськими чи американськими зразками, які не $\epsilon$ в усьому придатними до східно- та західнослов'янських реалій. Сьогодні все частіше пишуть про різні «постмодернізми» в контексті європейського літературного простору» [Бедзір $2008: 4]$.

Появу постмодернізму як нової філософсько-естетичної системи мислення та світовідчуття більшість дослідників схильні віднести до другої половини XX століття, вважаючи ії кризою мистецтва, культури, зрештою - кризою філософії. У даній ситуації доречним є твердження Д. Затонського, який наголошує, що «постмодернізм - явище тимчасове, яке періодично виникало в історії, коли руйнувалася чергова утопія «про створення раю на землі» та «наставав період тверезого розчарування» [Затонський $2002: 7]$. 
Суголосною є думка М. Рошка, який зазначає, що перші спроби дискусій щодо постмодернізму починають з'являтися уже у 1960-ті роки, але як цілісний феномен сучасної культури він став розглядатися тільки починаючи з 80-х років минулого століття [Рошко 2003 : 5]. Принагідно зауважити, що сам термін «постмодернізм» вперше 3'явився у праці Р. Ранвіца «Криза європейської культури», а згодом був використаний $\Phi$. де Оніза на позначення авангардистських поетичних спроб, які радикально відкидали попередню літературну традицію.

Пізніше А.- Дж. Тойнбі у своїй праці «Вивчення історії» вживає поняття постмодернізм на позначення радикальної епохи, яка стає символом краху західного культурно-релігійного панування. Протягом 1960 - 1970-х рр. поняття використовувалось для фіксації новітніх тенденцій в архітектурі та мистецтві. Термін «постмодернізм» набув свого поширення завдяки появі дослідження Ч. Дженкса «Мова постмодерністської архітектури». Починаючи 3 появи дослідження «Постмодерністський стан: доповідь про знання» Ж.- Ф. Ліотара у 1979 р., термін «постмодернізм» утверджується у статусі філософської категорії, яка позначає «ментальну специфіку сучасної епохи», відкидає традицію загалом і засвідчує епістемологічний розрив з філософією модернізму, тим самим продукуючи початок нового світогляду. Але тут варто зауважити, що постмодернізм, хоч і дистанціює себе як від класичної, так і від некласичної традиції, та все ж генетично сягає своїм корінням некласичного типу філософствування, зокрема, філософії Гайдеггера, постструкруралізму, структурного психоаналізу та ін.

Згодом помічаємо появу постмодернізму i в літературі. Щодо виникнення терміну «постмодернізм» у літературознавстві, то тут варто зазначити, що спочатку він вживався на визначення поетичної школи «чорна гора», яка існувала в 50 -х роках XX століття у США. Важливим підгрунтям виникнення у США літератури постмодернізму була, в першу чергу, література хіпі. Саме тому американських письменниківпостмодерністів досі часто називають «чорними гумористами». 
Принагідно, що саме американський літературознавець I. Хассан початку 70-х років поклав початок наукового вивчення постмодернізму як транскульурного явища, визначивши такі його основні характеристики: карнавалізація, багатозначна іронія, невизначеність, фрагментарність, деканонізація, відсутність самості, брак глибини, поверховість, непрезентабельність, ірреалістичність, деформація жанрів культури, текст постмодернізму вимагає відтворення, іманентність [Хассан $2002: 125]$.

Як бачимо, дослідник називає ознаки, що притаманні усім сферам сучасного культурного життя, яке найкраще можна зафіксувати за допомогою терміну «постмодернізм», а стан ментальності, що його усвідомлює, як «постмодерн».

Проте насьогодні дослідники літератури не можуть дійти консенсусу щодо того, коли з'явився постмодернізм, як трактувати і поціновувати дане явище. Тут не можна не погодитися 3 думкою В. Гладишева, що «саме визначення постмодернізм відбувається в дещо іншій системі координат, ніж це було узвичаєно, так як початком відліку стає не естетична самобутність періоду в розвиткові літератури, а певна часова субстанція - «пост», тобто - «після чогось». Тому таке визначення акцентує не на самій літературі, а на місці цього періоду в істориколітературному процесі» [Гладишев 2005 : 107].

Значна кількість дослідників постмодернізму вбачають його коріння у стилі бароко, який, за словами Е. д’Орса, є категорією позачасовою й неісторичною. Постмодернізм, як і бароко, характеризує період зламу ціннісних переорієнтації, переосмислення традицій. Про це ж говорить О. Юрчук, наголошуючи, що «такі тенденції увібрали у себе весь комплекс ознак, іманентних кризовим ситуаціям, що призвело до їх модифікованого повторення в інших часових межах літературного розвитку» [Юрчук 2013 : 188]. Про суголосність бароко і постмодернізму говорить і Н. Городнюк, зазначаючи, що «кінець XX століття засвідчив значне зростання інтересу літературознавців, культурологів, філософів до проблеми мови культури бароко, що стає надзвичайно актуальним у контексті необарокових 
тенденцій, які виразно окреслюються в сучасному постмодернізмі і вимагають свого осмислення та інтерпретації» [Городнюк 2006 : 7].

Пов’язувати поняття «постмодернізм» із необароко стали від початку 3 90-х років, адже близькість між явищами у царині світогляднофілософських орієнтирів, культурної рефлексії, у засобах відображення стану людини в той чи інший кризовий період є очевидною.

Саме у площині небарокових витоків починають говорити про постмодернізм в українських реаліях 80-90-х рp. минулого століття. Виявом нового світовідчуття українських письменників стала поява так званих творів-парабол. Елементи карнавалізації, іманентності, іронії у своїх творах застосовували О. Ільченко «Козацькому роду нема переводу...», Р. Федорів «Жбан вина», В. Дрозд «Ирій», Ю. Щербак «Хроніка міста Ярополя», Є. Гуцало «Приватне життя феномена», «Позичений чоловік», В. Земляк «Зелені млини», «Лебедина зграя», В. Шевчук «Дім на горі» та ін.

Якщо сьогодні $€$ усталеною думка щодо появи західного постмодернізму як опозиції до модернізму, то дещо іншою $є$ ситуація виникнення постмодернізму на українському грунті. Українська література, не зважаючи на тривалі перешкоди, все ж приєдналася до світового літературного процесу.

3 проголошення незалежності в Україні склалися сприятливі умови для відродження української культури, зокрема літератури як іï вагомої складової. Можливим стало утвердження iï самобутності, переоцінка здобутків попередніх поколінь, неприйняття соцреалістичного канону i розвитку власної, націєтворчої літератури, яка впевнено виходить на нові жанрово-стильові рубежі. Нова епоха почала вимагати від митців не тільки нового світовідчуття та пошуку самоідентичності, а й нових форм зображення реальності, нових виражальних засобів. Це яскраво відбивається в розвитку сучасної літератури. Широке коло науковців потратктовують українську літературу останньої третини XX - початку XXI століття як постмодерну. 
Так, починаючи з 90-х років, у вітчизняному літературознавстві розпочалася жвава дискусія навколо питань часу появи постмодернізму в українській літературні, потрактування його засадничих основ та визначення естетичної цінності. У цьому питанні вітчизняні дослідники займають полярні позиції: одні вважають (Т. Гундорова, Р. Харчук, В. Даниленко, I. Старовойт, М. Павлишин), що постмодернізм $\epsilon$ закономірним етапом розвитку сучасного українського суспільства й літератури зокрема, інші - що його існування не $\epsilon$ можливим у силу багатьох обставин (Є. Баран, Я. Поліщук, С. Квіт, О. Ільницький, І. Фізер). Таку позицію критики пояснюють тим, що в Україні свого часу не досяг апогею свого розвитку модернізм як естетико-культурний попередник постмодернізму. Однак, зважаючи на транскультурність постмодернізму, маємо підстави говорити про можливість його паралельного існування 3 модернізмом на теренах сучасної української літератури.

Обидві тези заслуговують на існування, проте сучасна українська література безперечно є явищем зовсім іншого, нового гатунку.

Таким чином, проаналізувавши особливості появи та розвитку постмодернізму у західній культурі та в Україні, можемо висловити власний погляд на появу та особливості побутування явища постмодернізму в західній літературі та на теренах української реальності. Сьогодні постмодернізм, без перебільшення, $\epsilon$ одним 3 найбільш обговорюваних явищ в сучасному вітчизняному літературознавстві. Оцінка його естетичної вартості часто коливається від уславлення до повного неприйняття та відкидання самої можливості існування українського варіанту постмодернізму. Однак, не зважаючи на наявність таких думок, все ж варто визнати, що український постмодернізм існує, хоч і має суттєві відмінності від свого західного аналогу. I це не дивно, адже кожна національна література є відображенням життя певного народу. Саме тому неправомірним буде вимагати однаковості постмодернізму в різних літературах. Якщо західна його модель найчастіше $\epsilon$ реакцією на літературу модернізму, то український різновид $\epsilon$ протиставленням радянському соцреалізму, естетичним викликом до усього тоталітарного 
режиму СРСР. Звідси і маємо позиціонування українського варіанту постмодернізму як пострадянського та постколоніального напряму в літературі і культурі з принциповим націєтворчим колоритом.

\section{БІБЛІОГРАФІЯ}

Бедзір 2008 - Бедзір Н.П. Російська постмодерністська проза в східно- та західнослов'янському літературному контексті: автореф. дис. на здобуття наук. ступеня д-ра філол. наук: спец.10.01.02 / Н.П. Бедзір. - К., 2008. - 40 с.

Гладишев 2005 - Гладишев В.В. Як розгадати «сни людства?» До вивчення поняття постмодернізм / В.В. Гладишев // Тема. - 2005. - № 1 - 2. C. 106-111.

Городнюк 2006 - Городнюк Н.А. Знаки необарокової культури Валерія Шевчука: компаративні аспекти / Н.А. Городнюк. - К. : «Твімінтер», 2006. $216 \mathrm{c}$.

Затонский 2002 - Затонский Д. Закономерно ли возникновение постмодернизма? К вопросу о цикличности развития искусства / Д. Затонский // Всесвітня література в середніх навчальних закладах України. - 2002. - № 5-6. C. 7-9.

Рошко 2003 - Рошко М.М. Постмодернізм у зарубіжній літературі: «Ім'я троянди» У. Еко; «Парфумер. Історія одного вбивці» П. Зюскінда; «Політ над гніздом зозулі» К. Кізі / М. М. Рошко. - Ужгород : Мистецька лінія, 2003. - 56 с.

Хассан 2002 - Хассан Ихаб. Культура постмодернизма / Ихаб Хассан / Современная западно-европейская и американская эстетика: сб. переводов / ред. Е. Г. Яковлев. - М. : Книжный дом «Университет», 2002. - С. 124-139.

Юрчук 2013 - Юрчук О. У тіні імперії. Українська література у світлі постколоніальної теорії / О. Юрчук. - К. : ВЦ «Академія», 2013. - 224 с.

Літератури світу: поетика, ментальність і духовність. - 2014. - Вип. 4. 